\title{
Induction of Placental Heme Oxygenase-1 Is Protective Against TNF $\alpha$-induced Cytotoxicity and Promotes Vessel Relaxation
}

\author{
Asif Ahmed, Mahbubur Rahman, Xian Zhang, Carmen H. Acevedo, \\ Sarbjit Nijjar, Ian Rushton, Benedetta Bussolati, and Justin St. John \\ Department of Reproductive and Vascular Biology, Division of Reproductive and \\ Child Health, The University of Birmingham, Birmingham Women's Hospital, \\ Edgbaston, Birmingham, U.K.
}

Accepted February 9, 2000.

\begin{abstract}
Background: Pregnancy is characterized by an inflammatory-like process and this may be exacerbated in preeclampsia. The heme oxygenase $(\mathrm{HO})$ enzymes generate carbon monoxide (CO) that induces blood vessel relaxation and biliverdin that acts as an endogenous antioxidant.

Materials and Methods: We examined the expression and localization of $\mathrm{HO}-1$ and $\mathrm{HO}-2$ in normal and preeclamptic placenta using reverse transcription polymerase chain reaction (RT-PCR), RNase protection assay, immunoblotting and immunohistochemistry. In addition, the effect of $\mathrm{HO}$ activation on tumor necrosis factor-alpha (TNF $\alpha$ ) induced placental damage and on feto-placental circulation was studied.

Results: We provide the first evidence for the role of $\mathrm{HO}$ as an endogenous placental factor involved with cytoprotection and placental blood vessel relaxation. HO-1 was significantly higher at term, compared with first trimester placentae indicating its role in placental vascular development and regulation. HO-1 predominantly localized in the extravascular connective tissue that forms the perivascular contractile sheath around the developing blood vessels. HO-2
\end{abstract}

\begin{abstract}
was localized in the capillaries, as well as the villous stroma, with weak staining of trophoblast. Induction of HO- 1 caused a significant attenuation of $\mathrm{TNF} \alpha-$ mediated cellular damage in placental villous explants, as assessed by lactate dehydrogenase leakage $(p<0.01)$. HO-1 protein was significantly reduced in placentae from pregnancies complicated with preeclampsia, compared with gestationally matched normal pregnancies. This suggests that the impairment of HO-1 activation may compromise the compensatory mechanism and predispose the placenta to cellular injury and subsequent maternal endothelial cell activation. Isometric contractility studies showed that hemin reduced vascular tension by $61 \%$ in U46619-preconstricted placental arteries. Hemininduced vessel relaxation and CO production was inhibited by HO inhibitor, tin protoporphyrin IX.

Conclusions: Our findings establish HO-1 as an endogenous system that offers protection against cytotoxic damage in the placenta, identifies the $\mathrm{HO}-\mathrm{CO}$ pathway to regulate feto-placental circulation and provides a new approach to study the disease of preeclampsia.
\end{abstract}

\section{Introduction}

Preeclampsia is a maternal hypertensive disease affecting $7-10 \%$ of all first-time pregnancies. It is characterized by hypertension, pro-

Address correspondence and reprint requests to Prof. A. S. Ahmed, Department of Reproductive and Vascular Biology, Division of Reproductive and Child Health, Birmingham Women's Hospital, University of Birmingham, Edgbaston, Birmingham, B15 2TG, U.K. Phone/Fax: $44+121627$ 2705; E-mail: A.S.Ahmed@bham.ac.uk teinuria, reduced utero-placental circulation and endothelial cell dysfunction. It is a major cause of maternal death and contributes significantly to perinatal morbidity. Moreover, women with prior preeclampsia are characterized by hyperinsulinemia and a 2- to 3-fold excess risk of hypertension and ischemic heart disease in later life $(1,2)$. Preeclampsia is associated with reduced utero-placental circulation leading to poor placental perfusion, local hy- 
poxia and secretion of cytotoxic factors into the maternal blood with consequent widespread circulatory disturbances secondary to endothelial dysfunction (3). The cause of preeclampsia is unknown. The placenta is implicated since the delivery of the placenta is the only known cure for this disease. Although the identity of any specific cytotoxic factor is unknown, preeclamptic sera can cause endothelial dysfunction and inhibit the ability of vasorelaxants to relax preconstricted blood vessels (4). The major research efforts have concentrated on identifying factors for the initiation and maintenance of the pathological processes in preeclampsia. Recently, it was suggested that preeclampsia is a disease of exacerbation of an inflammatory process characteristic of normal pregnancy, but lacking a compensatory system (5). Tumor necrosis factor-alpha (TNF $\alpha)$, a cytokine produced mainly by macrophages, is involved in the induction of oxygen free radicals (6). The level of TNF $\alpha$ in the maternal circulation is increased prior to the clinical manifestation of preeclampsia. In addition, placental TNF $\alpha$ protein and mRNA expression are reported to be elevated and to correlate with increased placental lipid peroxidation in this disorder (6), supporting the role of this cytokine in the endothelial dysfunction noted in preeclampsia. Little is known about the role of endogenous placental factors that may be responsible for counteracting the inflammatory response of pregnancy.

Activation of the microsomal enzymes heme oxygenases (HO) appears to offer cellular protection (7). Degradation of heme by HO generates carbon monoxide (CO), together with biliverdin (an antioxidant) and free iron (a gene regulator). Two main isozymes of $\mathrm{HO}$ are $\mathrm{HO}-1$ (inducible) and $\mathrm{HO}-2$ (constitutive). The HO-2 is present in high concentration in brain, testis and vascular endothelium; whereas, HO-1 is widely distributed in the body (7). In a human case of HO-1 deficiency, there is severe, persistent endothelial damage, as indicated by marked elevation in thrombomodulin and von Willerand factor (8). It was suggested that the induction of HO-l directly regulates endothelial cell activation, as it prevented the oxidative stress-induced expression of adhesion molecules $(9,10)$. Like nitric oxide (NO), carbon monoxide (CO) is an endogenously produced vasorelaxant molecule that activates soluble guanylate cyclase leading to an increase in intracellular guanosine 3',5'-cyclic monophosphate (cGMP) (11). Exogenous $\mathrm{CO}$ induces vascular smooth muscle relaxation (12) and regulates blood pressure in rats (13). Unlike nitric oxide synthase (NOS), HO-l activation exerts protection in various oxidative stress conditions (14). The products of HO-l activation are thought to act as potent endogenous factors for the resolution of stress-induced inflammatory injury (15-17).

The control of feto-placental circulation is unique, since it lacks autonomic innervation (18). The vasomotor regulation of the smooth muscle cells surrounding the villous arterioles plays a pivotal role in maintaining the blood flow within the placenta. A variety of circulating and local substances regulate vasomotor control of the smooth muscle surrounding the stem villous arterioles within the placenta vasculature (19-24). A physiological role for nitric oxide (NO) in the regulation of vascular tone was supported by the observation that NO maintained low vascular tone in the fetoplacental circulation of the isolated, dualperfused human cotyledon in vitro $(19,20)$. Under hypoxia, however, NO production and endothelial nitric oxide synthase (eNOS) expression are suppressed (25-27) and the vessel tone is then probably modulated by hypoxia mediated factors. $\mathrm{HO}-1$ is induced rapidly after oxidative stress conditions, such as hypoxia $(28,29)$. Moreover, exogenous $\mathrm{CO}$ was shown to counteract the stimulating effect of hypoxia on the transcription of a number of genes, including erytropoietin, endothelin, platelet-derived growth factor-B and vascular endothelial growth factor in endothelial cells (7).

This study provides the first evidence to support a role for heme oxygenase (HO) as an endogenous cytoprotective pathway in human placenta that is responsible for counteracting the physiopathological insults during pregnancy. It shows that HO- 1 exhibits a highly specific pattern of expression during placental vascular evolution and that HO-1 expression is reduced in placental tissue obtained from pregnancies complicated by preeclampsia. This indicates that placenta from such pregnancies may lack the compensatory mechanism to increased shear stress. It also demonstrates that the $\mathrm{HO}-\mathrm{CO}$ system acts as a local physiological vasoregulator of the feto-placental circulation, thus providing a new approach for pharmacological manipulation that may have therapeutic relevance. 


\section{Materials and Methods}

\section{Materials and Drug Preparation}

All chemicals were obtained from Sigma Chemical Co. Ltd. (Poole, Dorset, U.K.) or as otherwise cited. Rabbit polyclonal anti-HO-1 and anti-HO-2 were purchased from StressGen Biotechnologies Corporation (Victoria, Canada). Hemin, tin protoporphyrin IX (SnPP), and hemoglobin were dissolved in $0.1 \mathrm{M} \mathrm{NaOH}$, to which phenol-free Dulbecco's modified Eagle's medium (DMEM) or Krebs solution was added, and the $\mathrm{pH}$ was adjusted to 7.4. All reagents were prepared and stored in the dark. $N^{\mathrm{G}}$-methyl-L-arginine (L-NMA) was dissolved in Krebs solution.

\section{Tissue Collection}

Placental biopsies were obtained after termination (first trimester: 7-12 weeks of gestation; second trimester: 15-22 weeks) and after elective Caesarean sections from normal pregnancies at third trimester (27-35 weeks of gestation) or at term (37-40 weeks of gestation). Placental biopsies were obtained from pregnancies complicated with preeclampsia (27-34 weeks of gestation) and those complicated with severe intrauterine growth restriction (IUGR; 33-38 weeks of gestation). Preeclampsia was diagnosed when blood pressure was at least $140 / 90 \mathrm{mmHg}$ or greater in a previously normotensive woman after 20 weeks gestation, and that there was at least $300 \mathrm{mg} /$ day proteinuria, platelet count $<150,000 / \mathrm{ml}$ and urate $>350 \mathrm{mmol} / \mathrm{l}$. At least two such blood pressure recordings were obtained on consecutive occasions, $4 \mathrm{hr}$ apart. All subjects in the preeclampsia group were investigated in the puerperium to ensure that they were normotensive with no significant proteinuria at 20 weeks postdelivery. IUGR placental tissues were obtained from women with absent end diastolic flow velocity and small-for-dates babies with fetal weight less than the fifth percentile for gestational age. Placental tissues were taken from a central location, lying between the basal and chorionic plates. Amnion and chorion (chorionic laeve) were from reflected membranes formerly covering the decidua parietalis of the uterus. Fetal membranes were separated manually and washed in ice-cold sterile normal saline. Tissues were immersed in $10 \%$ formaldehyde or snap-frozen in liquid nitrogen immediately after collection. Ethical committee approval for tissue collection was obtained from the South Birmingham Ethical Committee.

\section{Tissue and Cell Preparation}

For tissue explant experiments, a full cotyledon was biopsied, the maternal side was dissected and the tissue collected in ice-cold phenol-red free DMEM. Villous fragments or chorio-decidua were obtained by gentle dissection of the tissue. The fragments were equilibrated for $6 \mathrm{hr}$ in phenol-free DME medium containing $0.1 \%$ bovine serum albumin (BSA), $1 \%$ L-glutamine, and $1 \%$ antibiotic mixture (5,000 IU/ml penicillin and $5000 \mu \mathrm{g} / \mathrm{ml}$ streptomycin) at $37^{\circ} \mathrm{C}$ in a $95 \% \mathrm{O}_{2} / 5 \% \mathrm{CO}_{2}$ incubator. Spontaneously transformed first-trimester cytotrophoblast-like cell line $\left(\mathrm{ED}_{27}\right)$ generated by repeated passaging of trophoblast obtained from first-trimester tissue by chorionic villous sampling was a gift from Dr. D. A. Kniss. Firsttrimester trophoblast cells were maintained at $37^{\circ} \mathrm{C}$ in a $95 \% \mathrm{O}_{2} / 5 \% \mathrm{CO}_{2}$ incubator, in $175 \mathrm{~cm}^{2}$ flasks, in a 1:1 mixture of DMEM, Hams F-12 nutrient mixture (DMEM/Ham-F-12). DMEM/ Ham-F-12 nutrient mixture also contained $15 \%$ (volume per volume; v/v) fetal calf serum, $1 \%$ L-glutamine, and $1 \%$ antibiotic mixture $(5,000 \mathrm{IU} / \mathrm{ml}$ penicillin and $5000 \mu \mathrm{g} / \mathrm{ml}$ streptomycin). Confluent monolayers were trypsinized with EDTA-trypsin. Cells were plated at $150 \times 10^{3}$ cells/well in 24 -well plates for experimental procedures. Monolayers at over $80 \%$ confluence were serum-starved in serum-free DMEM/F-12 containing $0.1 \%$ BSA for $24 \mathrm{hr}$.

\section{Amplification of Placental $\mathrm{HO}-1$ and $\mathrm{HO}-2$ cDNA Fragments}

Total RNA from full-thickness term placenta, first-trimester tissue, fetal membranes and first-trimester human trophoblast cells were prepared using RNAzol ${ }^{\circledR}$ and quantified spectrophotometrically at $260 \mathrm{~nm}$. HO-1 and HO-2 cDNAs were synthesised from $5 \mu \mathrm{g}$ of total RNA by reverse transcription (RT) using oligo $\mathrm{d}(\mathrm{T})$ and, then, amplified by polymerase chain reaction (PCR) with the SuperScript ${ }^{\circledR}$ pre-amplification system (Life Technologies Ltd., Paisley, U.K.) in 35 thermal cycles as described previously (30). Primers were designed according to the published sequence of human monocyte $\mathrm{HO}-1$ and rat testis HO-2. 
The forward (5'-GAATTCAGCATGCCCCAGGATTTG-3') and the reverse (5'-TCTAGACTAGCTGGATGTTGAGCAGGA-3') primers for HO- 1 were used to amplify a 615-bp fragment, and the forward (5'-GAATTCGGGACCAAGGAAGCACAT-3') and the reverse (5'-TCTAGACTATGTAGTACCAGGCCAAGA-3') primers for HO-2 were used to amplify a 828-bp fragment. The PCR products were subcloned and sequenced to confirm their identity (30). To ensure that RNA was free of genomic DNA, total RNA was also treated with RNase-free DNasel. Total RNA from rat brain was used as positive control.

\section{RNase Protection Assays}

Total RNA was isolated from snap frozen placental tissue by homogenization in guanidinium isothiocyanate, followed by acidic phenol/chloroform extraction. The human HO-1 probe template consisted of a cDNA fragment in the vector pCRScript (Stratagene, Amsterdam, Netherlands), corresponding to nucleotides 883-1242 of the sequence described by Yoshida et al. (31). HO-l antisense RNA was transcribed by T3 RNA polymerase after linearization with XhoI, in the presence of $\alpha\left[{ }^{32} \mathrm{P}\right]-$ UTP (Amersham, Buckinghamshire, UK), using standard methods, and on hybridization, protected a 359-nucleotide fragment.

A probe for human $\beta$-actin was used as an internal standard and transcribed from the pTRI- $\beta$-Actin-125-Human antisense control template (Ambion, Witney, Oxon, UK) with T3 RNA polymerase. On hybridization, this probe protected a 127-nucleotide fragment. Probes for HO-1 (1.0-5.0 $\left.\times 10^{5} \mathrm{cpm}\right)$, and $\beta$-actin $\left(1.0-5.0 \times 10^{4} \mathrm{cpm}\right)$ were combined with $10 \mu \mathrm{g}$ of total placental RNA and coprecipitated. RNase protection assays were then performed using the RPA II kit (Ambion, Witney, Oxon), according to the manufacturers instructions. Protected fragments were resolved on $6 \%$ denaturing polyacrylamide gel electrophoresis (PAGE) gels, transferred to Whatmann $3 \mathrm{~mm}$ paper and dried under vacuum in a gel drier. Autoradiography was performed using X-ray film (Kodak Biomax MR, New York, NY) with intensifying screeens a $-70^{\circ} \mathrm{C}$ for $2-3$ days. After autoradiography, the intensities of HO-1protected species and their respective $\beta$-actin signals were quantitated using the Gelbase densitometry software.

\section{Western Blots Analysis}

Total protein was extracted from tissue in high-salt buffer $[0.4 \mathrm{M} \mathrm{KCl}, 20 \mathrm{mM} \mathrm{N}-2$ hydroxyethylpiperazine- $\mathrm{N}$-2-ethane sulfonic acid (HEPES), 1 mM DL-Dithiothreitol (DTT), $20 \%$ glycerol, $0.5 \mathrm{mg} / \mathrm{ml}$ bacitracin, 40 $\mathrm{mg} / \mathrm{ml}$ phenylmethylsulfonyl fluoride (PMSF), $5 \mathrm{mg} / \mathrm{ml}$ pepstatin, $5 \mathrm{mg} / \mathrm{ml}$ leupeptin]. An equal amount of total protein $(100 \mu \mathrm{g})$ for each sample was loaded in $10 \%$ sodium dodecyl sulfate (SDS)-polyacrylamide mini-gel and separated by electrophoresis. Proteins from the gels were electro-transferred to prewetted nitrocellulose membrane (Amersham, Bucks, UK) and subjected to immunoblot analysis. The membranes were blocked in Tris-buffered saline containing 1\% Tween-20, 10\% dry skimmed milk, 5\% BSA, and $2 \%$ goat serum for $1 \mathrm{hr}$ to prevent nonspecific binding of the antibodies. Membranes were then incubated with either a polyclonal rabbit anti-rat $\mathrm{HO}-1$ (1:1000) or a polyclonal rabbit anti-rat HO-2 (1:1000) antibodies (StressGen Biotechnologies Corp., Victoria, Canada). Bands were detected with the nonradioactive enhanced chemiluminescent protein (ECL) Western Blotting System (Amersham), exposing the membranes to X-ray film (X-Omat AR, Eastman Kodak Company, New York, NY) to record chemiluminescence and bands were quantitated using a laser densitometer UVP ImageStore 5000 combine system (UVP Ltd., Cambridge, UK). Recombinant protein was used as positive control. Protein determination was carried out by the Bio-Rad protein assay (BioRad Laboratories Ltd., Herts, UK) using bovine serum albumin (BSA) as standard.

\section{Lactate Dehydrogenase Assay}

Cytotoxicity can be measured as leakage of lactate dehydrogenase (LD) into the culture medium from tissues $(30,32)$. The cytotoxicity index was expressed as a percentage ratio of LD leakage into media/LD in tissue $\left(\mathrm{LD}_{\mathrm{m}} / \mathrm{LD}_{\mathrm{t}}\right)$. Placental villous fragments were equilibrated for $6 \mathrm{hr}$ in phenol-free DME medium containing $0.1 \% \mathrm{BSA}, 1 \% \mathrm{~L}$-glutamine, and $1 \%$ antibiotic mixture at $37^{\circ} \mathrm{C}$ in a $95 \% \mathrm{O}_{2} / 5 \% \mathrm{CO}_{2}$ incubator. After overnight exposure of tissue explants to vehicle (control) or $\mathrm{TNF} \alpha$ $(50 \mathrm{ng} / \mathrm{ml})$ in the absence and presence of hemin $(5 \mu \mathrm{M})$ or SnPP $(20 \mu \mathrm{M})$, tissue was homogenized and $100 \mu \mathrm{l}$ aliquots of the homogenates and $100 \mu \mathrm{l}$ of explant media were 
mixed with LD reagent (Sigma Diagnostics, St Louis, MO). LD activity was measured using an UV DU640 spectrophotometer (Beckman Instruments Inc., Fullerton, CA). The rate of increase in the absorbance at $340 \mathrm{~nm}$ due to NADH formation was recorded for $60 \mathrm{sec}$ to give LD activity expressed as U/L. The cytotoxicity index was expressed as the ratio of $\mathrm{LD}_{\mathrm{m}} / \mathrm{LD}_{\mathrm{t}}$.

\section{Immunohistochemistry}

Serial $8-\mu \mathrm{m}$ formalin-fixed, wax-embedded term placental $(n=6)$ and first-trimester $(n=$ 4) sections were immunostained for $\mathrm{HO}-1$ and HO-2 as previously described (30). Sections were incubated with the primary antibodies (HO-1 or HO-2) at a 1:500 dilution in PBS containing $10 \%$ normal goat serum and $0.3 \%$ Triton X-100 for $1 \mathrm{hr}$ at room temperature. Amplification of primary antibody reaction was achieved by incubation of sections with a goat anti-rabbit secondary antibody (DAKO Ltd., Bucks, UK) followed by a complex of streptavidin/biotinylated peroxidase (DAKO Ltd.) Binding was visualized by incubation of sections in $0.5 \mathrm{mg} / \mathrm{ml}$ diaminobenzidine and $0.01 \% \mathrm{H}_{2} \mathrm{O}_{2}$ in PBS. Sections were counterstained with Mayer's haematoxylin (Raymond A. Lamb, London, UK), dehydrated and mounted. Consecutive sections were incubated in $10 \%$ normal goat serum in PBS for $1 \mathrm{hr}$ at room temperature, in the absence of the primary antibody as negative control. Adsorption experiments were performed on anti-HO-1 and anti-HO-2 to confirm the specificity of antibody binding. The immunostaining protocol was repeated using adsorbed antisera in parallel. Adsorption was achieved by incubation of primary antibodies (diluted to a final concentration of $10 \mu \mathrm{g} / \mathrm{ml}$ ) overnight at $37^{\circ} \mathrm{C}$ with purified $\mathrm{HO}-1$ and $\mathrm{HO}-2$ proteins (StressGen Biotechnologies Corp.), respectively. Consecutive sections were immunostained for $\alpha$ actin-1 (AutogenBioclear Ltd., Wiltshire, UK), which confirmed that the immunoreactive cells for HO-1 and HO-2 were smooth muscle-like cells.

An arbitrary 4-point scale was used to grade the intensity and the proportion of positively stained cells. A score of four-plus $(++++)$ indicated very intense staining of more than $95 \%$ of cells, compared with a score of minus (-), which indicated an absence of staining. A score of one-to three-plus indicated slight $(+)$, moderate $(++)$, and strong $(+++)$ staining, respectively. Both immunohistochemistry and the scoring of positively stained cells were performed by a single individual, without prior knowledge of the HO antibodies used for the study.

\section{Contractility Studies in Placental Vessels}

Tissue samples of placental vessels were obtained from term elective Caesarian sections. The second or third branches of placental arteries (approx. $3 \mathrm{~mm}$ in diameter) were carefully isolated and immersed in the icecold Krebs solution (composition in $\mathrm{mM}$ : $\mathrm{NaCl} 118, \mathrm{KCl} 4.75, \mathrm{KH}_{2} \mathrm{PO}_{4} 1.2, \mathrm{MgSO}_{4}$ 1.2, $\mathrm{CaCl}_{2}$ 2.5, $\mathrm{NaHCO}_{3} 25$, glucose 11). The vessels were cleared of excess connective tissue and blood traces and dissected into $3 \mathrm{~mm}$ long rings. Two adjacent rings from the same vessel were secured separately for control and test substances in two separate organ baths. This was achieved using two stainless steel hooks, one of which was fixed and the other attached to an isometric transducer as described previously (30). The isometric changes in tension were recorded through the transducer to a pen-recorder (Harvard Universal Oscillograph). The organ baths were filled to a volume of $1 \mathrm{ml}$ with Krebs solution and gassed with a $95 \% \mathrm{O}_{2}$ and $5 \% \mathrm{CO}_{2}$ mixture. The temperature of organ baths was maintained at $37^{\circ} \mathrm{C}$ by using an outer water bath. The vessels were adjusted to a tension of $300 \mathrm{mg}$ and were allowed to equilibrate for 60 min, during which the Krebs solution was changed at 15 min intervals and the tension repeatedly readjusted. $\mathrm{KCl}(75 \mathrm{mM})$ was applied during the experiments to prove the contractility of the vessels. To examine the vasorelaxant effect of hemin, the vessels were first preconstricted with $10^{-7}$ M U46619, a thromboxane $\mathrm{A}_{2}$ mimetic. This dose was previously shown to cause $70 \%$ of maximal contractile response, compared with $75 \mathrm{mM} \mathrm{KCl}$. Hemin $(5 \mu \mathrm{M})$ was added when the placental artery reached a contractile plateau. In selected experiments, the effects of SnPP $(20 \mu \mathrm{M})$, a selective HO inhibitor, or of L-NMA (1 mM), a NOS inhibitor, on hemininduced relaxation were tested. Hemin was added to the vessels after the addition of the inhibitors, when the vessels had reached a new steady-state. In the absence of changes in tension, hemin was added after $30 \mathrm{~min}$. The changes in tension by the drugs were com- 
pared with the previous contraction induced by $10^{-7} \mathrm{M}$ of U46619.

\section{Measurement of Carboxy-hemoglobin in Conditioned Media}

Production of CO was determined in term placental villous explants, fetal membranes and first-trimester trophoblast cells by the estimation of the proportion of carboxy-hemoglobin $(\mathrm{COHb})$ in the media as previously described $(29,33)$. Samples were stimulated with vehicle (control), $5 \mu \mathrm{M}$ hemin, $20 \mu \mathrm{M}$ SnPP and hemin plus SnPP in phenol-free DMEM/F12 containing $0.1 \%$ BSA for the time indicated. Hemoglobin $(50 \mu \mathrm{M})$ was then added for the last hour of incubation. At the end of the incubation, $100 \mu \mathrm{l}$ of sample was added to $1150 \mu \mathrm{l}$ of $0.1 \mathrm{M}$ potassium phosphate buffer containing sodium hydrosulfite $\left(\mathrm{Na}_{2} \mathrm{~S}_{2} \mathrm{O}_{4}\right)$ in a cuvette. After 10 min incubation in the dark, absorbance was read at $420 \mathrm{~nm}$ and $433 \mathrm{~nm}$ in an UV DU640 spectrophotometer (Beckman Instruments Inc., Fullerton, CA). Absorbance values were used to determine $\% \mathrm{COHb}$ per $\mathrm{mg} / \mathrm{ml}$ of total protein using the formula given below:

$$
\begin{aligned}
\% \mathrm{COHb}=1 & -\left(\mathrm{AR} \times \mathrm{F}_{1}\right) / \mathrm{AR}\left(\mathrm{F}_{2}-\mathrm{F}_{1}\right) \\
& -\mathrm{F}_{3}+1
\end{aligned}
$$

where: $A R$ is the ratio of $A_{420} / A_{432}$ of the sample; and $F_{1}, F_{2}$, and $F_{3}$ are constant $\left(F_{1}=1.330\right.$; $\left.\mathrm{F}_{2}=0.4787 ; \mathrm{F}_{3}=1.9939\right)$.

\section{Results}

\section{Expression of $\mathrm{HO}-1$ and $\mathrm{HO}-2$ in Human Placenta}

RT-PCR analysis revealed that mRNAs encoding both HO-1 and HO-2 were expressed in first-trimester and term placenta, as well as fetal membranes (Fig. 1A). The expected cDNA fragments of $615 \mathrm{bp}$ for HO-1 and $815 \mathrm{bp}$ for HO-2 were amplified from total RNA extracted from first-trimester and term placenta, and fetal membranes (Fig. 1A). HO-1 and HO-2 mRNA were also expressed in cultured first-trimester human trophoblast (Fig. 1B). Positive control used for HO-1 was total RNA from rat spleen (RS) and for HO-2 rat brain (RB).

Western blots analysis demonstrated the expression of HO-1 (32 kDa heat-shock protein) immunoreactive protein in human placenta and fetal membranes (Fig. 2A). Corresponding laser densitometric analysis revealed that the inducible $\mathrm{HO}-\mathrm{l}$ protein expression


Fig. 1. Amplification of inducible heme oxygenase (HO-1) and constitutive heme oxygenase (HO-2) mRNA by reverse transcription polymerase chain reaction (RT-PCR) in human placenta, fetal membranes and first-trimester human trophoblast cells. A 625-bp fragment corresponding to $\mathrm{HO}-1$ and a 828-bp fragment corresponding to $\mathrm{HO}-2$ were amplified from $5 \mu \mathrm{g}$ of total RNA. (A) Term placenta (1); first trimester tissue (2); amnion (3) and chorio-decidua (4).

(B) First trimester human trophoblast cells (Troph). Total RNA from rat spleen (RS) and brain (RB) served as positive control for $\mathrm{HO}-1$ and HO-2, respectively. To ensure that RNA was free of genomic DNA, total RNA was treated with RNasefree DNase 1. M, 100-bp ladder.

A

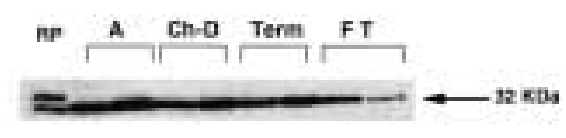

B

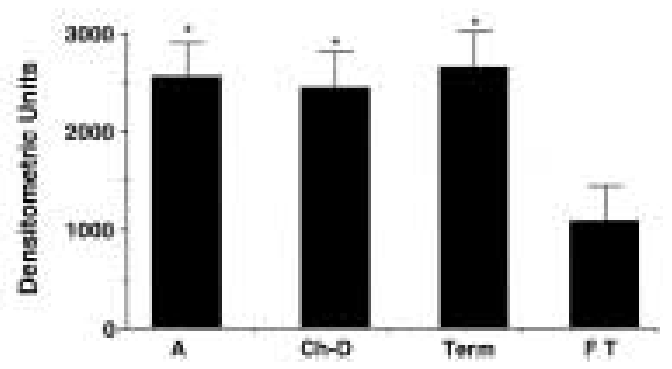

Fig. 2. Western blots analysis for heme oxygenases in human placenta and fetal membranes. (A) expression of inducible heme oxygenase (HO1; $32 \mathrm{kDa}$ heat shock protein) proteins in amnion (A), chorio-decidua (Ch-D), term placenta (Term) and first-trimester tissue (FT). (B) Corresponding laser densitometric analysis for HO-1. Recombinant protein (RP) was used as positive control. ${ }^{*} p<$ 0.05 vs first trimester. $n=6$. 
was 2.6-fold higher in full-thick placentae at term, compared with first-trimester tissues (Fig. 2B; $p<0.05, n=6$ ). The level of HO-1 protein expression between amnion and chorio-decidua samples at term showed no significant difference and was similar to that observed in the full-thick placenta samples at term (Fig. 2B; $n=6$ ). There was no significant difference in the level of expression of HO-2 among these tissues (data not shown).

Levels of HO-1 mRNA were determined throughout gestation using RNAse protection assay (Fig. 3A). Quantitation of autoradiographic signals by densitometric analysis of HO- $1 / \beta$-actin ratios showed relatively low abundance of placental HO- 1 mRNA in early pregnancy (7-12 weeks gestation) (Fig. 3B).

A



B

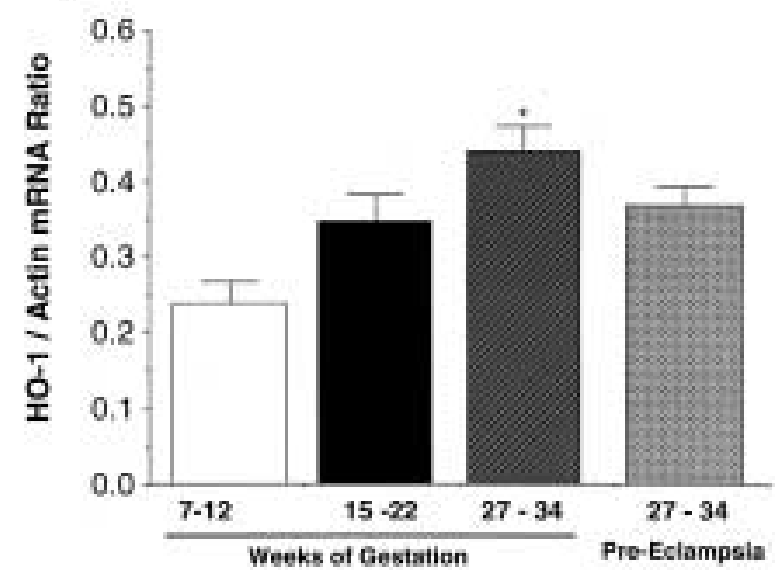

Fig. 3. Quantification of placental inducible heme oxygenase (HO-1) during early and late gestation and in preeclampsia. (A) Levels of HO1 detected in first trimester (FT), second trimester (ST) and third trimester (TT) and gestationally matched preeclamptic (PE) placenta. $\beta$-actin in each sample was used as an internal standard for the estimation of abundance of mRNA. RNAse protection assay was performed on samples of $10 \mu \mathrm{g}$ total RNA isolated from human placenta at various stages of gestation. No protected bands were detected in the negative control with $10 \mu \mathrm{g}$ yeast total
The level of HO-1 mRNA expression increased with increasing gestation and reached a significant increase during third trimester (27-34 weeks gestation), compared with early pregnancy (Fig. 3B). In pregnancies complicated with preeclampsia, HO-1 mRNA levels showed no significant change (Fig. 3A and $\mathrm{B})$. However, $\mathrm{HO}-1$ protein expression was significantly reduced, compared with gestationally matched normal third trimester pregnancies (Fig. 3C-D; $p<0.01, n=5$ ). In contrast, placental HO-1 protein was not reduced in pregnancies complicated with intrauterine growth restriction (IUGR), compared with normal pregnancies (Fig. 3; $p<$ $0.01, n=4)$. No apparent change was seen in the expression of $\mathrm{HO}-2$ protein in normal,


RNA (not shown). (B) Graphical representation of HO-1/actin mRNA from the above experiment. Autoradiographic signals for HO-l and actin are expressed as relative densitometric units. (C) Western blots analysis for HO-1 in third trimester (TT) and gestationally matched preeclamptic (PE) and uterine growth-restricted (IUGR) pregnancies. Expression of HO-1 is shown as $32 \mathrm{kDa}$ heat shock protein. (D) Corresponding laser densitometric analysis for HO-1. Recombinant protein (RP) was used as positive control. ${ }^{*} p<0.05$ vs FT; ${ }^{* *} p<0.01$ vs TT, $n=4$. 
preeclamptic and IUGR pregnancies (data not shown).

\section{Effect of Hemin on TNF $\alpha$-induced Lactate Dehydrogenase Leakage}

Term placental villous explants were incubated overnight with $50 \mathrm{ng} / \mathrm{ml} \mathrm{TNF} \alpha$ in the presence or absence of hemin to evaluate the cytoprotective role of $\mathrm{HO}-1$ in placental villi. TNF $\alpha$ caused cellular damage, as measured by the increased leakage of lactate dehydrogenase (LD) into the media (Fig. 4A; $p<0.001, n=8$ ). The cytotoxicity index $\left(\mathrm{LD}_{\mathrm{m}} / \mathrm{LD}_{\mathrm{t}}\right)$ was significantly reduced when the villous explants were preincubated with $5 \mu \mathrm{M}$ hemin for $2 \mathrm{hr}$ prior to the addition of TNF $\alpha$ (Fig. 4A; $p<0.001, n=8$ ). Western blots analysis showed that, in the presence of $\mathrm{TNF} \alpha$, hemin caused an upregulation of HO- 1 expression, compared with $\mathrm{TNF} \alpha$ (see insert in Fig. 4A). In contrast, TNF $\alpha$ itself decreased HO-1 expression, compared with contol or hemin. When preeclamptic villous fragments were treated as in A, it was apparent that under basal conditions the level of LD leakage was three times higher than in normal villous explants (Fig. 4B; $n=3$ ). Hemin failed to offer any protection and TNF $\alpha$ did not exacerbate the condition. To assess that the protective effect of hemin was due to HO pathway, tissue were preincubated with the $\mathrm{HO}$ in-

A
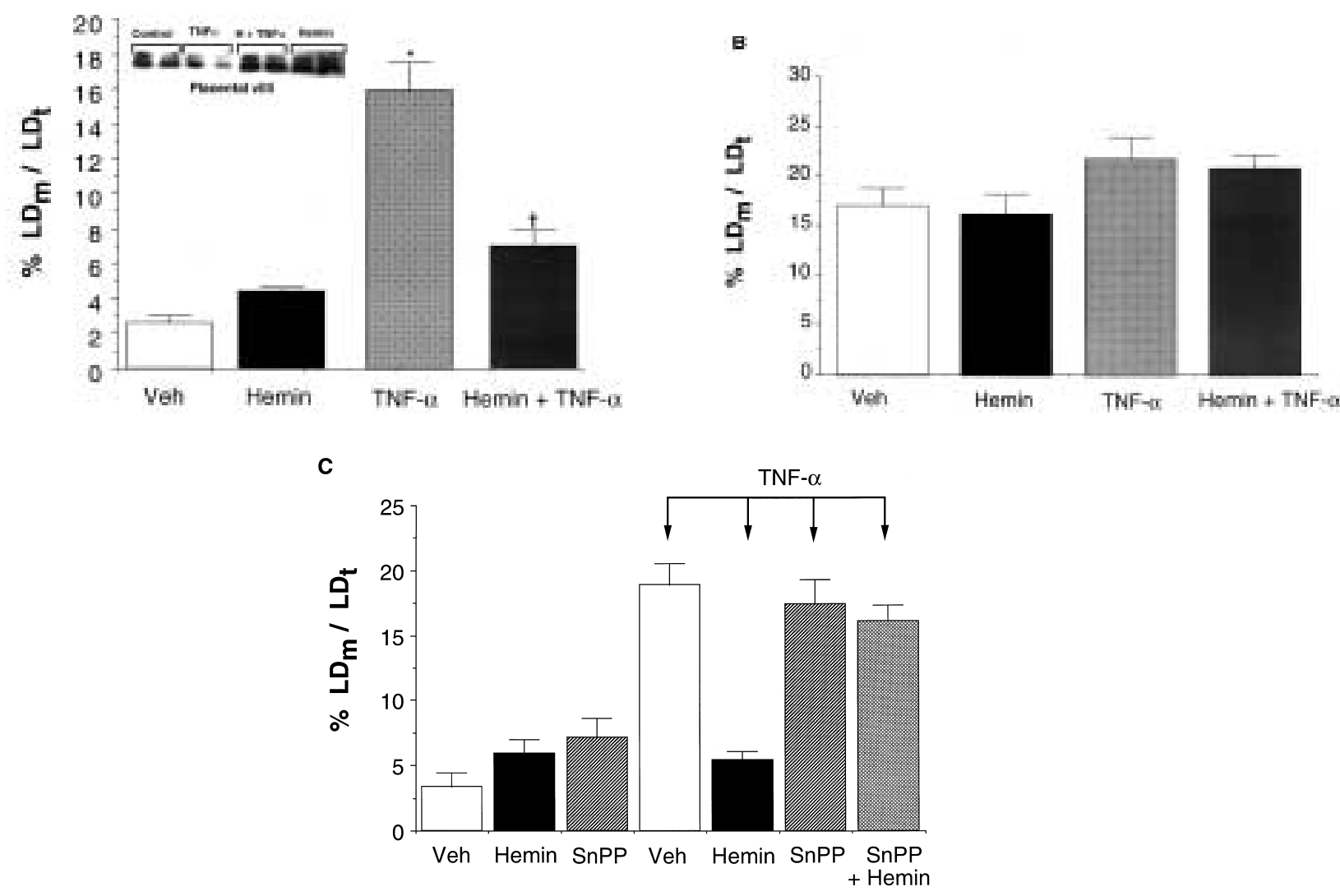

Fig. 4. Effect of hemin on tumor necrosis factor-alpha (TNF $\alpha$ )-induced cytotoxicity. Villous fragments from term (A) and preeclamptic (B) placenta were exposed to vehicle (open column), $5 \mu \mathrm{M}$ hemin (solid column), $50 \mathrm{ng} / \mathrm{ml} \mathrm{TNF} \alpha$ alone (crossed column) and TNF $\alpha$ added after 2 hr preincubation of villous fragments with $5 \mu \mathrm{M}$ hemin (dotted column). The insert in (A) shows Western blots for HO-1 protein expression in villous explants exposed to hemin and/or TNF $\alpha$ for $24 \mathrm{hr}$. (C) Villous fragments were incubated with either vehicle (Veh), $5 \mu \mathrm{M}$ hemin, $20 \mu \mathrm{M}$ tin protopor- phyri IX (SnPP), and $50 \mathrm{ng} / \mathrm{ml}$ TNF $\alpha$. In addition, TNF $\alpha$ was added after $2 \mathrm{hr}$ preincubation of villous fragments with $5 \mu \mathrm{M}$ hemin, SnPP alone and SnPP incubated for $60 \mathrm{~min}$ prior to the addition of hemin. In the presence of SnPP, the protective effect of hemin on $\mathrm{TNF} \alpha$-induced damage was totally abolished. The cytotoxicity index is expressed as a percentage ratio of lactate dehydrogenase (LD) leakage into media/LD in tissue $\left(\mathrm{LD}_{\mathrm{m}} / \mathrm{LD}_{\mathrm{t}}\right)$. A value of less then $5 \%$ was considered as viable tissue. Data represents the mean ( \pm S.E.M.) of eight separate experiments performed in duplicate. 
hibitor SnPP $(20 \mu \mathrm{M})$ for $60 \mathrm{~min}$ prior to the addition of hemin. In the presence of SnPP, the protective effect of hemin on $\mathrm{TNF} \alpha$-induced damage was totally abolished (Fig 4C; $n=4$ ). Incubation with $5 \mu \mathrm{M}$ hemin or with $20 \mu \mathrm{M}$ SnPP overnight did not increase LD leakage significantly, as measured by $\mathrm{LD}_{\mathrm{m}} / \mathrm{LD}_{\mathrm{t}}$. Term placental villous explants remained viable over the exposure period since the $\mathrm{LD}_{\mathrm{m}} / \mathrm{LD}_{\mathrm{t}}$ ratio was less than 5\% (Fig. 4).

\section{Immunolocalization of $\mathrm{HO}-1$ and $\mathrm{HO}-2$}

Adsorption experiments with purified HO-1 and HO-2 proteins confirmed the binding specificity of anti-HO-1 and anti-HO-2 antibodies (data not shown). Consecutive sections immunostained for $\alpha$-actin-1 confirmed that the immunoreactive cells for $\mathrm{HO}-1$ and $\mathrm{HO}-2$ were of contractile nature. The $\mathrm{HO}-1$ positivity in the placenta was differently localized during its developement $(7,9,10$, and 38 weeks) and appeared correlated with the placental vascularization (Fig. 5; Table 1). A perivascular stromal staining for HO- 1 was localized in the stromal condensation of the villous core in early pregnancy tissues, prior to the appearance of vessels. The intensity of the positivity increased with the development of muscularized stem vessels and was most intense in term placentae, in the chorionic plate and in the stem villi arising from the plate (Fig. 5a-c). The intensity gradually declined with branching of the stem villi and was largely absent in villi devoid of muscularized vessels (Fig. 5; Table 1). Fetal membranes showed strong immunoreactivity for the isozymes of HO. Immunostaining for HO-l was most intense in chorio-decidua (Fig. $5 \mathrm{~d}$ and e). No significant staining of the media or intima of the chorionic and stem villous vessels was observed. Staining of other components of the placenta, such as trophoblast and villous stromal cells not closely related to blood vessels, was weak and inconsistent (Fig. 5; Table 1).

The distribution and positivity for HO-2 was confined mainly to blood vessels, though the trophoblastic brush border and the villous stromal cells also showed a weak and irregular staining (Fig. $5 \mathrm{f}$ and $\mathrm{g}$ ). In early pregnancy (7-10 weeks), there was a specific staining of the basal cytotrophoblast. In term placental villi, there was an intense staining of the endothelium of the terminal villous capillary bed, weaker staining of the endothelium of larger vessels and weak staining of cells in the media of the muscularized vessels. $\mathrm{HO}-1$ and $\mathrm{HO}-2$ positivity of the decidua was intense in early pregnancy and appeared to decline at term of gestation (Table 1).

\section{Effect of Hemin on the Placental Vascular Contractility}

Placental vessel contractile activity was assessed using villous arterial rings mounted for isometric recording under $300 \mathrm{mg}$ tension and allowed to equilibrate for $60 \mathrm{~min}$. Figure 6 shows the time-course profile of the contraction of placental arterial vessels following the addition of a thromboxane $\mathrm{A}_{2}$ mimetic, U46619. A rapid and prolonged contraction in arterial rings was induced by $100 \mathrm{nM}$ U46619 with an $\mathrm{EC}_{50}$ value of $2.5 \times$ $10^{-8} \mathrm{M}$ and $\mathrm{E}_{\max }$ value of $95 \%$ of $75 \mathrm{mM}$ $\mathrm{KCl}$. Addition of hemin $(5 \mu \mathrm{M})$ to the preconstricted arterial rings caused a rapid fall in tension; whereas, contractile activity was maintained constant in control experiments using vehicle alone (Fig. 6). The insert shows that hemin induced over $60 \%$ reduction in tension at $30 \mathrm{~min}$ incubation timepoint $(p<0.05, n=5)$.

To test that the hemin-induced human placental vessel relaxation was due to the activation of the HO pathway, placental vessels were preincubated with the HO inhibitor, SnPP, for $30 \mathrm{~min}$ prior to the addition of hemin. Figure 7A shows that SnPP prevented a hemininduced fall in tension in human placental vessels preconstricted with U46619. Interestingly, a $15 \%$ reduction in tension by hemin on these preconstricted vessels was still observed in the presence of SnPP; whereas, the addition of SnPP itself did not alter vessel tension induced by U46619 (Fig. 7A).

The involvement of the NO pathway in the HO-mediated relaxation was investigated by preincubating preconstricted placental vessels with ImM L-NMA for $60 \mathrm{~min}$, prior to the addition of $5 \mu \mathrm{M}$ hemin. Addition of L-NMA itself did not alter vessel tension induced by U46619. L-NMA was also unable to prevent a hemin-induced fall in tension in human placental vessels preconstricted with U46619, because hemin induced a $60 \%$ and $54 \%$ fall in tension in the absence and presence of L-NMA, respectively (Fig. 7B and C; $n=4$ ). In contrast, hemin-induced relaxation of these vessels was 


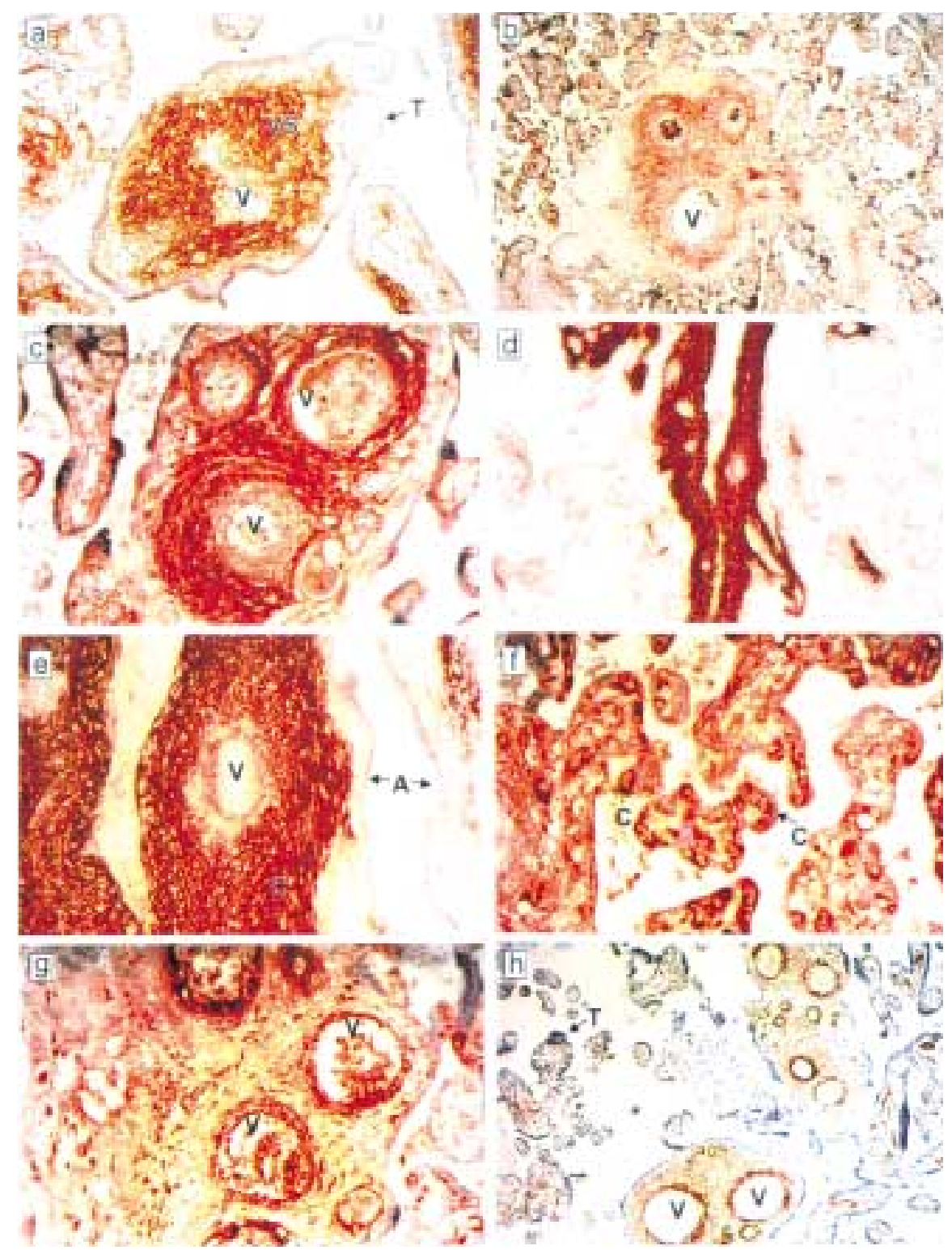

Fig. 5. Immunolocalization of inducible heme oxygenase (HO-1) and constitutive heme oxygenase (HO-2) in placental villi and fetoplacental membranes. Panel (a) shows first trimester villi (7 weeks) and panel (b) shows placental villi at term (37 weeks), stained with antiHO- 1 antibody. Strong staining for HO- 1 is localized in the perivascular villous stromal (VS) and weaker staining in trophoblast layer (labelled " $\mathrm{T}$ " and arrowhead in panel (a). Panel (c) shows intense staining in the large blood vessels $(\mathrm{V})$ of the stem villi at term (38 weeks). Panels (d-e) show

significantly attenuated by SnPP (Fig. 7C; $p<$ $0.01 ; n=4)$.

\section{Production of CO In Placenta and Fetal Membranes}

To establish whether the HO-CO system was functionally active within the human placenta, very strong HO-1 staining in the chorio-decidual cells ("C") and weak staining in the amnion (labelled " $\mathrm{A}$ " and arrowhead in panel (e). Panels (f-g) show HO-2 immunoreactivity. Intense staining of the endothelium of the terminal villous capillary bed (C) at term is shown in panel (f). In the endothelium of large blood vessels ( $\mathrm{g}$ ) and the media of the muscularized vessels, there is strong staining for HO-2. Panel (h) shows staining with $\alpha$-actin in term placenta. Magnifications: $350 \times$, panel c, e, g; $284 \times$, panel a, b, d, f; and $142 \times$, panel h.

villous fragments from term placentae were exposed to hemin for up to $24 \mathrm{hr}$ and CO production was calculated by measuring the percentage of $\mathrm{COHb}$ in the conditioned media as described in "Materials and Methods." Firsttrimester throphoblast cell line released CO into 
Table 1. Degree of positivity for inducible heme oxygenase (HO-1) and constitutive heme oxygenase (HO-2) immunostaining

\begin{tabular}{|c|c|c|c|c|c|c|}
\hline & \multicolumn{3}{|c|}{ HO-1 } & \multicolumn{3}{|c|}{ HO-2 } \\
\hline & \multicolumn{3}{|c|}{ Weeks of Gestation } & \multicolumn{3}{|c|}{ Weeks of Gestation } \\
\hline & 7 & 10 & 39 & 7 & 10 & 39 \\
\hline Trophoblastic brush border & + & - & - & + & + & + \\
\hline Syncytial trophoblast & $+1-$ & - & - & - & - & - \\
\hline Cytototrophoblast & - & - & - & ++ & + & - \\
\hline Villous stromal cells & + & + & + & + & $+1-$ & - \\
\hline Perivascular stromal cells & ++ & +++ & ++++ & + & ++ & + \\
\hline Stem vessel media & - & - & - & - & - & - \\
\hline Endothelium/intima & - & - & $+1-$ & $+1-$ & $+1-$ & +++ \\
\hline Decidua & +++ & +++ & ++ & ++ & ++ & ++ \\
\hline Chorion & ++ & +++ & +++ & + & + & + \\
\hline Amnion & $+1-$ & - & + & + & $+1-$ & + \\
\hline
\end{tabular}

Immunoreactivity is expressed as slight $(+)$, moderate $(++)$, strong $(+++)$ and intense $(++++)$.

Variable or equivocal staining $(+/-)$. No staining $(-)$.



Fig. 6. The effect of hemin on vascular tension in preconstricted placental arteries. Human placental arteries were preconstricted with $100 \mathrm{nM}$ U46619 (a thromboxane A2 mimetic) until steady state of tension was achieved. Thereafter, $5 \mu \mathrm{M}$ hemin or vehicle was added. A typical recording trace showing the tension in response to hemin (solid line) and to vehicle alone (dashed line) is shown. The insert shows the effect of hemin at 30 min incubation timepoint on the mean change in tension induced by U46619. Data represent the mean \pm S.E.M. of five separate experiments. ${ }^{*} p<$ 0.01 vs U46619. 
A

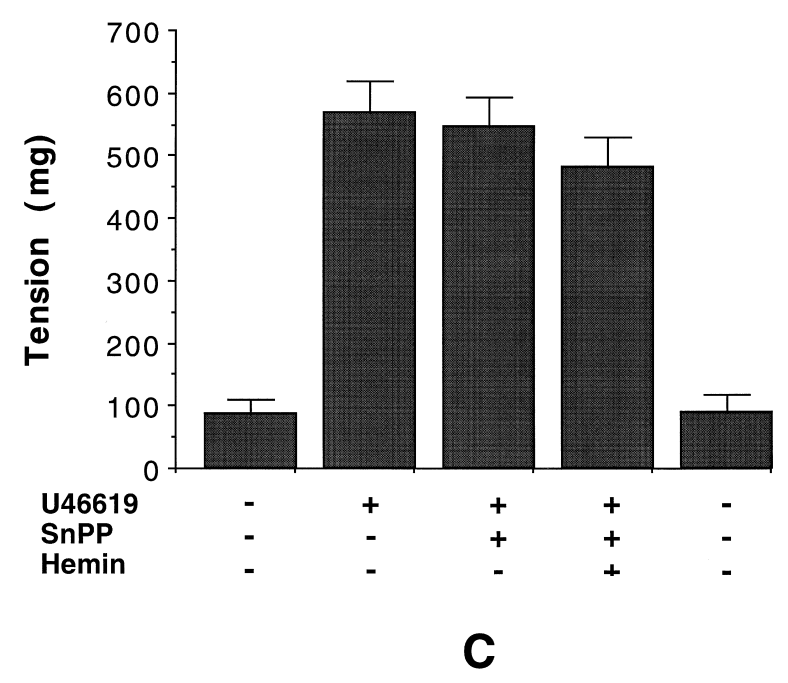

B

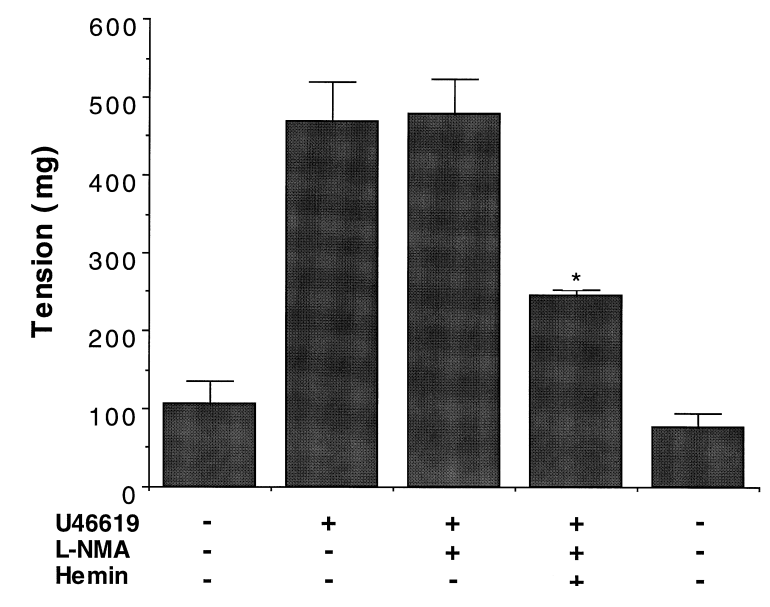

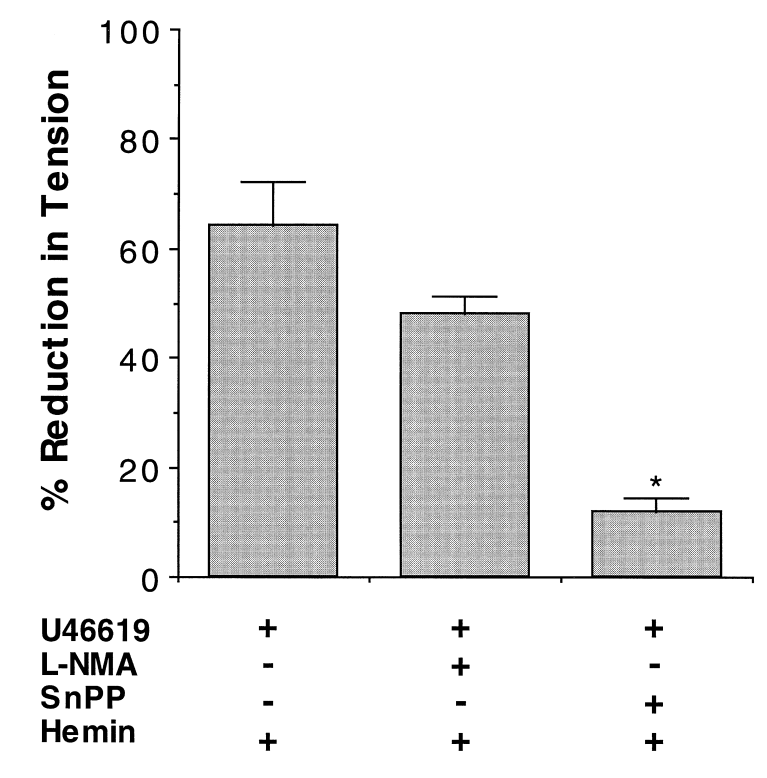

Fig. 7. Effect of tin protoporphyrin IX (SnPP) and $\mathrm{N}^{\mathrm{G}}$-methyl-L-arginine (L-NMA) on hemininduced relaxation in the preconstricted placental arteries. Human placental arteries were preconstricted with $100 \mathrm{nM} \mathrm{U} 46619$ (a thromboxane $A_{2}$ mimetic) until steady state tension was achieved. The change of tension was examined after administration of each tested drug for $30 \mathrm{~min}$. (A) Addition of $5 \mu \mathrm{M}$ hemin to U46619-preconstricted arteries

the culture medium; however, stimulation with hemin did not potentiate $\mathrm{CO}$ production (Fig. 8A). Figure 8B insert shows that hemin induced a transient $\mathrm{CO}$ production in the villous fragments (Fig. 8B; $n=3$ ). The $\mathrm{CO}$ release peaked after $2 \mathrm{hr}$ incubation with $5 \mu \mathrm{M}$ hemin, but returned to basal values after $4 \mathrm{hr}$ incuba-

after 30-min incubation in the presence of $20 \mu \mathrm{M}$ SnPP did not significantly reduce tension. (B) Addition of $5 \mu \mathrm{M}$ hemin in the presence of $1 \mathrm{mM} \mathrm{L}_{\mathrm{L}}$ NMA significantly reduced tension. The changes of tension represent the mean \pm S.E.M. of five separate experiments. " $p<0.01$ vs U46619. (C) Percentage reduction in tension U46619-preconstricted arteries induced by hemin alone, hemin plus L-NMA or hemin plus SnPP. ${ }^{*} p<0.01$ vs hemin.

tion. Preincubation with the HO inhibitor, SnPP (20 $\mu \mathrm{M}$ for $60 \mathrm{~min}$ ), significantly attenuated hemin-induced $\mathrm{CO}$ production in these villous fragments (Fig. 8B; $p<0.01, n=3$ ). In fetal membranes, after $2 \mathrm{hr}$ incubation with hemin, there was a significant increase in $\mathrm{CO}$ release (Fig. 8C; $p<0.01, n=3$ ). In parallel experi- 


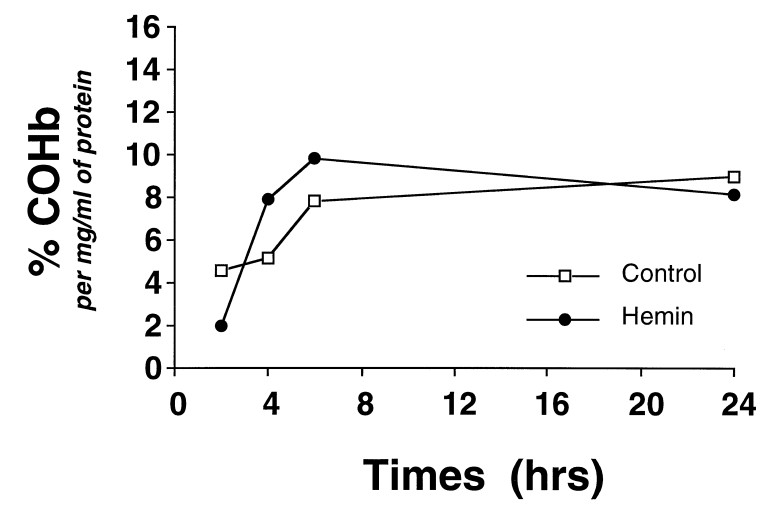

B

Fig. 8. Hemin mediated carbon monoxide release. Tissue and cells were exposed to hemin and carbon monoxide levels determined as a measure of the percentage of carboxyhemoglobin $(\mathrm{COHb})$ in the media. (A) First-trimester trophoblasts were exposed to $5 \mu \mathrm{M}$ hemin for up to $24 \mathrm{hr}$. (B) The effect of HO inducer and $\mathrm{HO}$ inhibitor on $\mathrm{CO}$ production in placental explants. Tissue was exposed to $20 \mu \mathrm{M}$ SnPP (HO inhibitor) for $\mathrm{l} \mathrm{hr}$ and then incubated with $5 \mu \mathrm{M}$ hemin for $2 \mathrm{hr}$. An inset shows the

ments, cell toxicity was evaluated as leakage of LD in the media. Incubation with $5 \mu \mathrm{M}$ hemin or with $20 \mu \mathrm{M}$ SnPP for $24 \mathrm{hr}$ did not increase LD leakage significantly, as measured by $\mathrm{LD}_{\mathrm{m}} / \mathrm{LD}_{\mathrm{t}}$.

\section{Discussion}

HO- 1 activation displays protective cellular effects through its enzymatic actions. One of its products, bilirubin, displays anti-complement
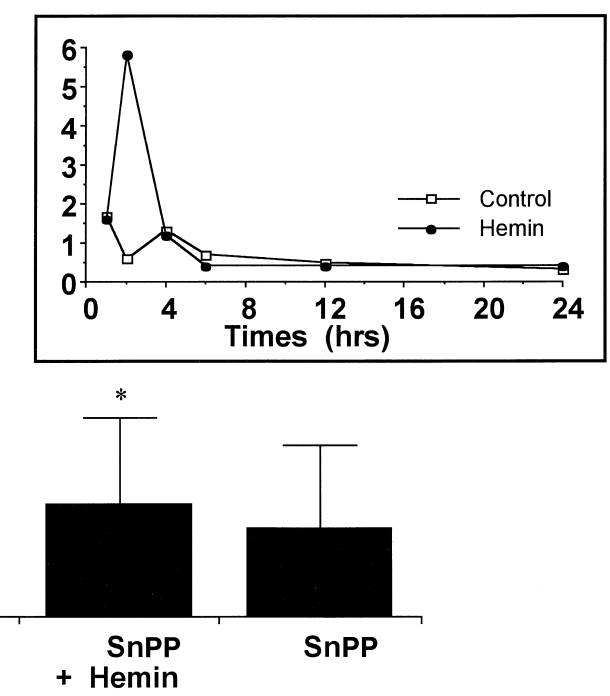

effect of hemin $(5 \mu \mathrm{M})$ on CO production from term villous fragments over a 24 -hr period. (C) Fragments of chorio-decidua were exposed to $5 \mu \mathrm{M}$ hemin for up to $24 \mathrm{hr}$. CO release is expressed as a percentage of carboxyhemoglobin $(\% \mathrm{COHb})$ in the conditioned media and standardized per $\mathrm{mg} / \mathrm{ml}$ of total protein. Data are shown as the mean \pm S.E.M. of three separate experiments performed in triplicate. ${ }^{*} p<0.01$ vs hemin; ${ }^{* *} p<0.001$ vs vehicle.

(17) and anti-oxidant (34) effects; whereas, its other product, $\mathrm{CO}$, has anti-platelet and vasodilatatory properties $(35,36)$. In vivo, HO- 1 is implicated in the protection against endotoxin and hyperoxia-induced lung injury in rats $(37,38)$. Moreover, NO-induced protection during myocardial ischemia and reperfusion damage is dependent at least in part, on $\mathrm{HO}$ activation (39).

Little is known about the role of endogenous placental factors that may be responsible 


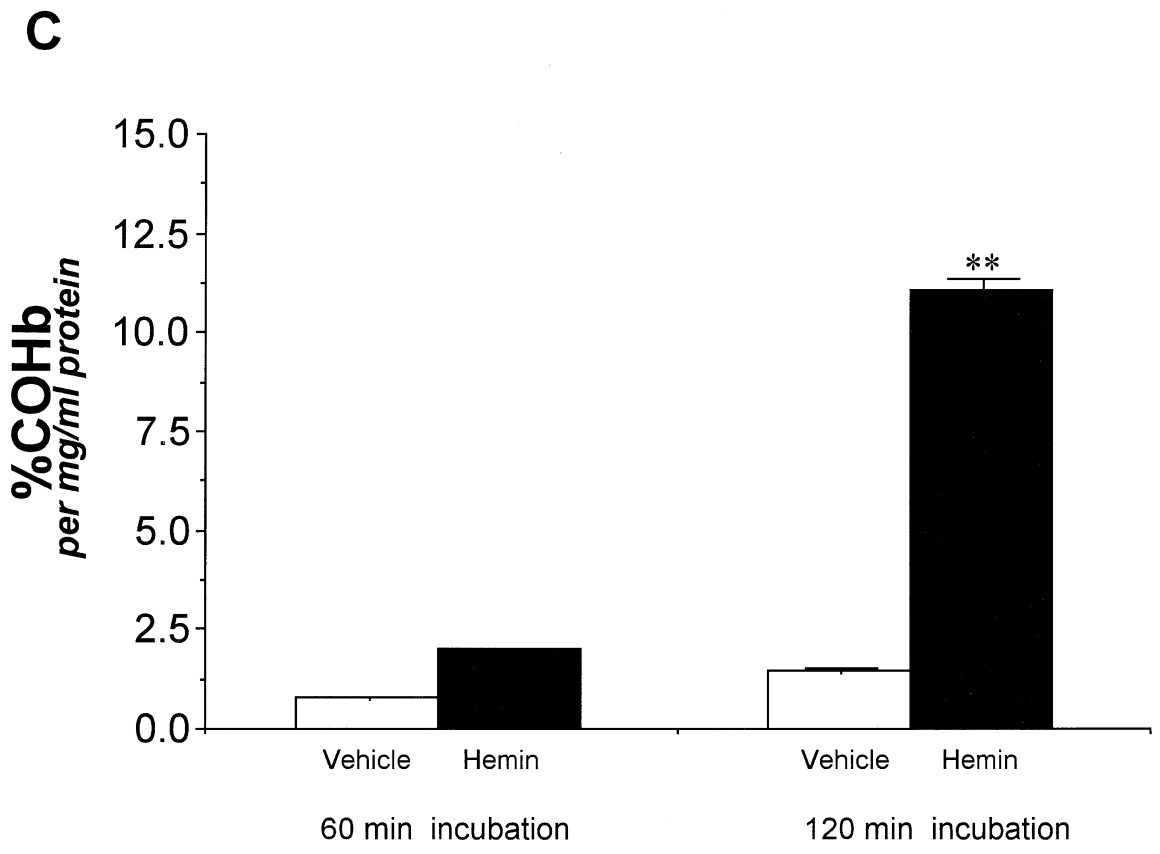

Fig. 8. (Continued)

for counteracting the inflammatory response of pregnancy. The studies described here provide evidence that $\mathrm{HO}$ has a role in an endogenous placental protective pathway for counteracting physiopathological insults during pregnancy. We demonstrate the presence of both isoforms of HO in human placenta and show that the HO-CO system offers cellular protection against TNF $\alpha$-induced cytotoxic damage in the placenta. The activation of HO-1 significantly reduces $\mathrm{TNF} \alpha$-mediated LD leakage from placental villous explants and the HO inhibitor, SnPP, reverses the inhibitory effect of hemin on $\mathrm{TNF} \alpha$-mediated LD leakage, indicating $\mathrm{HO}$ selective placental protection. One of the HO products, bilirubin induces suppression of hydrogen peroxide-mediated cell death in endothelial cells in vitro (40) and HO inhibition attenuates the cytoprotective effect of $\mathrm{NO}$ on $\mathrm{TNF} \alpha$ cytotoxicity (41). Although TNF $\alpha$ pretreatment confers resistance to hypoxic stress in the adult cardiac myocyte (42), in the placenta, it appears to cause cellular damage. It was recently suggested that preeclampsia is a disease of the exacerbation of an inflammatory process characteristic of normal pregnancy, but lacking a compensatory system (3). A number of studies suggest that $\mathrm{HO}-\mathrm{l}$ acts as a potent endogenous factor for the resolution of stressinduced inflammatory injury (14-17). The present study provides molecular evidence for the hypothesis that preeclampsia is a disease in which the vascular protective factors that normally counteract the inflammatory process characteristic of normal pregnancy are defective. It shows that $\mathrm{HO}-\mathrm{l}$ protein expression is reduced in placental tissue obtained from pregnancies complicated by preeclampsia. This suggests that HO protective pathway may be ineffective for counteracting physiopathological insults during pregnancy. Preeclampsia is associated with reduced utero-placental circulation, leading to poor placental perfusion that results in local hypoxia and secretion of cytotoxic factors into the maternal circulation that cause widespread circulatory disturbances secondary to endothelial dysfunction (1). It has been speculated that acute hypoxia and inflammation impair eNOS/NO production of the trophoblast in vivo, which might contribute to pathological conditions of gestational diseases (26). Ihara and co-workers (43) showed that, under acute fetal hypoxia, there was a decrease in HO-1 mRNA in the rat placenta. Although HO-1 mRNA levels did not change in placental tissue from preeclamptic women, compared with gestationally matched normal placenta, the level of HO-1 protein were significantly reduced, suggesting a translational blockage.

Lipid peroxidation also was suggested as a pathogenetic factor for preeclampsia, contributing to endothelial dysfunction (1). Lipid peroxi- 
dation products like malonlidialdehyde are increased and the activity of antioxidant enzymes, superoxide dismutase and glucose 6-phosphatedehydrogenase are decreased in preeclamptic placenta (44). One of the products of HO activation is bilirubin that is a lipid-soluble metabolite of the body. Bilirubin was reported to act as a physiological chain-breaking antioxidant of lipid peroxidation (34). A recent study showed that the concentrations of total bilirubin in pregnancy-induced hypertension were reduced significantly, compared with normal pregnancy (45). The results of the present study suggest that the reduced bilirubin observed by Chandra and colleagues (45) may be, in part, a result of decreased placental HO- 1 activation in preeclamptic placenta. In a human case of HO-l deficiency, there is severe, persistent endothelial damage, as indicated by marked elevation in thrombomodulin and von Willerand factor (8). It was suggested that the induction of HO-1 directly regulated endothelial cell activation as it prevented the oxidative stress-induced expression of adhesion molecules $(9,10)$. Exposure of HO-1 knockout mice to hypoxia results in an increase in lipid peroxidation and apoptosis in right ventricle of the heart (46). The impairment of HO-l activation in preeclamptic placenta could contribute to the endothelial activation and cytotoxicity observed in this pathology.

As in vivo angiogenesis is accompanied by vasodilation, the release of second-messenger gases such as $\mathrm{NO}$ and $\mathrm{CO}$ must regulate placental angiogenesis. NO is implicated in vascular remodeling (47). In placenta, the calciumdependent constitutive eNOS is localized in the villous vascular endothelium and villous syncytiotrophoblast $(48,49)$ and the calciumindependent inducible NOS isoform (iNOS) is localized to the Hofbauer cells in villous stroma, as well as in villous vascular endothelium and syncytiotrophoblast (22). The current study demonstrates the expression and distribution of the two isozymes, HO- 1 and HO-2, in human placenta and fetal membranes throughout gestation. RT-PCR analysis demonstrated that first-trimester placenta, term placenta and fetal membranes expressed mRNA encoding both HO-1 and HO-2. Western blots analysis showed that HO-l (inducible) protein expression was markedly lower in the first-trimester tissues, compared with the term placentae and fetal membranes. In contrast, Rutherford and colleagues (50) showed that eNOS protein was significantly greater in first-trimester, com- pared with normal term placentae (50). Endothelial cells transfected with the human HO1 gene increase growth and blood vessel formation (36). The distribution of placental HO isozymes, $\mathrm{HO}-1$ and $\mathrm{HO}-2$, show distinct topographic patterns. $\mathrm{HO}-1$ is localized predominantly in the extravascular connective tissue that forms the perivascular contractile sheath around the developing blood vessels. HO-1 exhibites a highly specific pattern of evolution with placental vascularisation. A recent study showed HO-1 immunoreactivity in the adventitial layer of the larger fetal blood vessels of the guinea-pig placenta (51). In contrast, $\mathrm{HO}-2$ isozyme was localized in the capilliaries as well as the villous stroma, with weak staining of trophoblast. The difference distribution of HO- 1 and HO-2 suggests that the HO isozymes exhibit differential roles in placental vessel development and regulation. In a recent study Shaw-Fang and coworkers reported that in HO-1 deficient mice, of the three characteristic responses to hypoxia (vascular remodeling, hypertension and hypertrophy of the right ventricle), only the latter was evident (52). The authors suggested that $\mathrm{CO}$ released by $\mathrm{HO}-2$ might be sufficient to balance for the lack of HO-1.

The feto-placental circulation lacks autonomic innervation (18). The vasomotor regulation of the smooth muscle cells surrounding the villous arterioles plays a pivotal role in maintaining the blood flow within the placenta. A physiological role for NO in the regulation of vascular tone was supported by the observation that NO maintained low vascular tone in the feto-placental circulation of the isolated dual-perfused human cotyledon in vitro $(19,20)$. Furthermore, generation of NO appears to attenuate the effect of vasoconstrictors, such as thromboxane $A_{2}$ and endothelin- 1 in the placental circulation (21). The present study shows that HO-CO system is a major contributor for placental blood vessel relaxation. Activation of $\mathrm{HO}-1$ by hemin causes marked relaxation in precontricted villous arterial rings that are prevented by $\mathrm{HO}$ inhibitor, but not by NOS inhibitor, indicating a selective action for hemin. Relaxation of placental arteries and $\mathrm{CO}$ production by hemin occurs concomitantly, indicating that the HO-CO system is active functionally within the placental vasculature. Placental and fetal membranederived $\mathrm{CO}$ may, therefore, play a pivotal role in the control of feto-placental vascular tone. 
Moreover, CO, like NO, inhibits platelet aggregation (35) and could also act as a platelet antiaggregating agent in the utero-placental circulation. Localization of $\mathrm{HO}-1$ to the perivascular contractile sheath of developing vessels and media of large stem vessels may indicate its importance for regulating fetoplacental circulation. The distribution of HO-2 suggests that it acts at the level of fetal capilliaries to prevent platelet adhesion and aggregation. The present study clearly shows that the NO-cGMP pathway is not the sole system for maintaining low vascular tone in the fetoplacental circulation, as previously reported $(21,22)$. Indeed, NO induces HO- 1 gene expression and $\mathrm{CO}$ production in vascular smooth muscle cells (53). Although endothelial-derived NO maintains normal resting blood vessel tone (54), under hypoxia, NO production and eNOS expression are suppressed $(25,27)$ and the vessel tone is probably modulated by hypoxia mediated factors. It is proposed that, while NO contributes to the physiological regulation of vessel tone, HO-CO pathway may act as a local regulator of the feto-placental circulation under conditions of hypoxia when NO levels are suppressed.

Fetal membranes are in close proximity to the myometrium. Our previous study showed that hemin inhibited oxytocin-induced myometrial contractility (30). The present study shows strong immunostaining for $\mathrm{HO}-\mathrm{l}$ in chorio-decidua, increased expression of HO-1 protein, as well as hemin-induced $\mathrm{CO}$ production from chorio-decidua. HO-l activation in fetal membranes may, therefore, contribute in maintaining the uterus in a state of relative quiescence during pregnancy. Clearly, the HO pathway displays multifunctional roles in human pregnancy, depending on its tissue distribution. Indeed, in early pregnancy, the expression of $\mathrm{HO}-\mathrm{l}$ and $\mathrm{HO}-2$ in extravillous trophoblast suggests a role for $\mathrm{HO}$ in uterine vascular remodeling. In preeclampsia (55) and in some cases of fetal growth restriction (56), the uterine blood vessels do not undergo adequate vascular transformation, due to the failure of trophoblast to successfully invade the maternal spiral arterioles. A recent study in the guinea-pig showed that increased dilation of the utero-placental arteries due to NO release was a prerequisite for trophoblast invasion and remodeling of the endothelium (57). It was proposed that the general ability of trophoblast to penetrate the spiral arterioles in order to remodel the endothelium may relate to the abil- ity of local autocoids to stimulate NO. Failure to generate adequate amounts of trophoblastderived NO may predispose women to preeclampsia (58). In a recent abstract publication, Lyall and coworkers (59) reported immunohistochemical localization of HO isozymes in extravillous trophoblast. Our finding that first-trimester trophoblast in culture releases CO suggests that trophoblast-derived CO may aid trophoblast penetration into the spiral arteries in early pregnancy. As basal CO levels are elevated and hemin is unable to further induce $\mathrm{CO}$ release from trophoblast cells, it suggests that the HO pathway may be active in these cells.

The present study shows distinct topographic patterns of distribution for placental $\mathrm{HO}$ isozymes and demonstrates that induction of HO-l offers protection against cytotoxic damage. As activation of $\mathrm{HO}-1$ promotes the relaxation of placental vessels, the $\mathrm{HO}-\mathrm{CO}$ system may be acting as a local vasoregulator of the feto-placental circulation and may be crucial under conditions of hypoxia. The observed reduced placental HO-1 expression by immunoblotting in preeclampsia may predispose the placenta to cellular injury and subsequent maternal endothelial cell activation. As preeclampsia could be a disease of the exacerbation of an inflammatory process characteristic of normal pregnancy, but lacking compensatory system, this reduction in placental HO-1 expression in preeclampsia suggests that the impairment of HO-1 activation may compromise the compensatory mechanism. It is likely that other endogenous vascular protective systems exist that protect the mother from developing the symptoms of preeclampsia. If the model is proven to be operational in vivo, it may provide a useful new approach to the study of this important disease.

\section{Acknowledgments}

This work was supported by the British Heart Foundation (Grant No: PG/96144 and RG/98/0003). We are grateful to Dr. D.A. Kniss (Ohio State University) for the gift of $\mathrm{ED}_{27}$ trophoblasts. We greatly acknowledge the support of the medical and technical staff of Birmingham Women's Hospital.

\section{References}

1. Jonsdottir LS, Arngrimsson R, Geirsson RT, Sigvaldason H, Sigfusson N. (1995) Death rates from ischemic heart disease in women with a 
history of hypertension in pregnancy. Acta $\mathrm{Ob}$ stet. Gynecol. Scand. 74: 772-776.

2. Hannaford P, Ferry S, Hirsch S. (1997) Cardiovascular sequelae of toxaemia of pregnancy. Heart 77: 154-158.

3. Roberts JM, Redman CW. (1993) Preeclampsia: more than pregnancy-induced hypertension. Lancet 341: 1447-1451.

4. Ashworth JR, Warren AY, Johnson IR, Baker PN. (1998). Plasma from preeclamptic women and functional change in myometrial resistance arteries. Br. J. Obstet. Gynaecol. 105: 459-461.

5. Redman CMJ, Sacks GP, Sargent IL. (1999) Preeclampsia: an excessive maternal inflammatory response to pregnancy. Am. J. Obstet. Gynecol. 180: 499-506.

6. Wang Y, Walsh SW. (1996) TNF alpha concentrations and mRNA expression are increased in preeclamptic placentas. Reprod. Immunol. 32: 157-169.

7. Maines MD. (1988) Heme-oxygenase: function, multiplicity, regulatory mechanisms, and clinical applications. FASEB J. 2: 2557-2568.

8. Yachie A, Niida Y, Wada T, et al. (1999) Oxidative stress causes enhanced endothelial cell injury in human heme oxygenase-1 deficiency. J. Clin. Invest. 103: 129-135.

9. Wagener FE, de Witte T, Abraham NG. (1997) Heme induces the expression of adhesion molecules ICAM-1, VCAM-1, and E selectin in vascular endothelial cells. Proc. Soc. Exp. Biol. Med. 216: 456-463.

10. Hancock WW, Buelow R, Sayegh MH, Turka LA. (1998) Antibody-induced transplant arteriosclerosis is prevented by graft expression of anti-oxidant and anti-apoptotic genes. Nat. Med. 4: 1392-1396.

11. Wang R, Wang Z, Wu L. (1997) Carbon monoxide-induced vasorelaxation and the underlying mechanisms. Br. J. Pharmacol. 121: 927-934.

12. Durante W, Schafer AI. (1998) Carbon monoxide and vascular cell function Int. J. Mol. Med. 2: 255-262.

13. Johnson RA, Lavesa M, DeSeyn K, Scholer MJ, Nasjletti A. (1996) Heme oxygenase substrates acutely lower blood pressure in hypertensive rats. Am. J. Physiol. 271: H1132-H1138.

14. Balla J, Jacob HS, Balla G, Nath K, Vercellotti GM. (1992) Endothelial cell heme oxygenase and ferritin induction by heme proteins: a possible mechanism limiting shock damage. Trans. Assoc. Am. Physicians 105: 1-6.

15. Nath KA, Balla G, Vercelotti GM, et al. (1992) Induction of heme oxygenase is a rapid, protective response in rhabdomyolysis in the rat. J. Clin. Invest. 90: 267-270.

16. Abraham NG, Lavrovsky Y, Schwartzman ML, et al. (1995) Transfection of the human heme oxygenase gene into rabbit coronary microvessel endothelial cells: protective effect against heme and hemoglobin toxicity. Proc. Natl. Acad. Sci. U.S.A. 92: 6798-6802.

17. Willis D, Moore AR, Frederick R, Willoughby DA. (1996) Heme oxygenase: a novel target for the modulation of the inflammatory response. Nat. Med. 2: 87-90.

18. Reilly FD, Russel PT. (1977) Neurohistochemical evidence supporting an absence of adrenergic and cholinergic innervation in the human placenta and umbilical cord. Anat. Rec. 188: 277-286.

19. Gude NM, King RG, Brennecke SP. (1990) Role of endothelium-derived nitric oxide in maintenance of low fetal vascular resistance in placenta. Lancet 336: 1589-1590.

20. Myatt L, Brewer A, Brockman DE. (1991) The action of nitric oxide in the perfused human fetal-placental circulation. Am. J. Obstetr. Gynecol. 164: 687-692.

21. Myatt L, Brewer AS, Langdonand G, Brockman DE. (1992) Attenuation of the vasoconstrictor effects of thromboxane and endothelin by nitric oxide in the human fetal-placental circulation. Am. J. Obstetr. Gynecol. 166: 224-230.

22. Myatt L, Eis AL, Brockman DE, Kossenjans W, Greer I, Lyall F. (1997) Inducible (type II) nitric oxide synthase in human placental villous tissue of normotensive, pre-eclamptic and intrauterine growth-restricted pregnancies. Placenta 18: 261-268.

23. Mandsager NT, Brewer AS, Myatt L. (1994) Vasodilator effects of parathyroid hormone, parathyroid hormone-related protein, and calcitonin generelated peptide in the human fetal placental circulation. J. Soc. Gynec. Invest. 1: 19-24.

24. Li X, Shams M, Zhu J, et al. (1998) Cellular localization of $\mathrm{AT}_{1}$ receptor $\mathrm{mRNA}$ and protein in normal placenta and its reduced expression in intrauterine growth restriction. Angiotensin II stimulates the release of vasorelaxants. J. Clin. Invest. 101: 442-454.

25. McQuillan LP, Leung GK, Marsden PA, Kostyk SK, Kourembanas S. (1994) Hypoxia inhibits expression of eNOS via transcriptional and posttranscriptional mechanisms. Am. J. Physiol. 267(5 Pt 2): H1921-H1927.

26. Kiss H, Schneeberger C, Tschugguel W, et al. (1998) Expression of endothelial (type III) nitric oxide synthase in cytotrophoblastic cell lines: regulation by hypoxia and inflammatory cytokines. Placenta 19: 603-611.

27. Faller DV. (1999) Endothelial cell responses to hypoxic stress. Clin. Exp. Pharmacol. Physiol. 26: 74-84.

28. Murphy BJ, Laderoute KR, Short SM, Sutherland RM. (1991) The identification of heme oxygenase as a major hypoxic stress protein in Chinese hamster ovary cells. Br. J. Cancer 64: 69-73. 
29. Morita T, Perrella MA, Lee ME, Kourembanas S. (1995) Smooth muscle cell-derived carbon monoxide is a regulator of vascular cGMP. Proc. Natl. Acad. Sci. U.S.A. 92: 1475-1479.

30. Acevedo $\mathrm{CH}$, Ahmed A. (1998) Hemeoxygenase- 1 inhibits human myometrial contractility via carbon monoxide and is upregulated by progesterone during pregnancy. J. Clin. Invest. 101: 949-955.

31. Yoshida T, Biro P, Cohen T, Muller RM, Shibahara S. (1996) Human heme oxygenase cDNA and induction of its mRNA by hemin. Eur. J. Biochem. 171: 457-461.

32. Chen Q, Galleano M, Cederbaum AI. (1997) Cytotoxicity and apoptosis produced by arachidonic acid in $\mathrm{HepG}_{2}$ cells overexpressing human cytochrome P450E1. J. Biol. Chem. 272: 14532-14541.

33. Beutler E, West C. (1984) Simplified determination of carboxyhemoglobin. Clinical Chemistry 30: 871-874.

34. Stocker R, Glazer AN, Ames BN. (1987) Antioxidant activity of albumin-bound bilirubin. Proc. Natl. Acad. Sci. U.S.A. 84: 5918-5922.

35. Brune B, Ullrich V. (1987) Inhibition of platelet aggregation by carbon monoxide is mediated by activation of guanylate cyclase. Mol. Pharmacol. 32: 497-504.

36. Deramaudt BM, Braunstein S, Remy P, Abraham NG. (1998) Gene transfer of human heme oxygenase into coronary endothelial cells potentially promotes angiogenesis. Cell Biochem. 68: $121-127$.

37. Otterbein L, Sylvester SL, Choi AM. (1995) Hemoglobin provides protection against lethal endotoxemia in rats: the role of heme oxygenase1. Am. J. Respir. Cell Mol. Biol. 13: 595-601.

38. Otterbein LE, Kolls JK, Mantell LL, Cook JL, Alam J, Choi AM. (1999) Exogenous administration of heme oxygenase-1 by gene transfer provides protection against hyperoxia-induced lung injury. J. Clin. Invest. 103: 1047-1054.

39. Maulik N, Engelman DT, Watanabe M, et al. (1996) Nitric oxide/carbon monoxide. A molecular switch for myocardial preservation during ischemia. Circulation 94 (9 Suppl): II398-II406.

40. Motterlini R, Foresti R, Vandegriff K, Intaglietta M, Winslow RM. (1995) Oxidative-stress response in vascular endothelial cells exposed to acellular hemoglobin solutions. Am. J. Physiol. 269: H648-H655.

41. Polte T, Obele S, Schroder H. (1997) The nitic oxide donor SIN-1 protects endothelial cells from tumor necrosis factor-alpha-mediated cytotoxicity: possible role for cyclic GMP and heme oxygenase. J. Mol. Cell Cardiol. 29: 3305-3310.

42. Nakano M, Knowlton AA, Dibbs Z, Mann DL. (1998) Tumor necrosis factor- $\alpha$ confers resis- tance to hypoxic injury in the adult mammalian cardiac myocyte. Circulation 97: 1392-1400.

43. Ihara N, Akagi R, Ejiri K, Kudo T, Furuyama K, Fujita H. (1998) Developmental changes of gene expression in heme metabolic enzymes in rat placenta. FEBS Lett. 439: 163-167.

44. Poranen AK, Ekblad U, Uotila P, Ahotupa M. (1996) Lipid peroxidation and antioxidants in normal and pre-eclamptic pregnancies. Placenta 17: 401-405.

45. Chandra L, Lali P, Jain A. (1996) Role of bilirubin in pregnancy-induced hypertension. Int. J. Gynaecol. Obstet. 53: 267-268.

46. Yet SF, Perrella MA, Layne MD, et al. (1999) Hypoxia induces severe right ventricular dilatation and infarction in heme oxygenase- 1 null mice. J. Clin. Invest. 103: R23-R29.

47. Nakaki T, Kato R. (1996) Nitric oxide in vascular remodeling. Jpn. Heart J. 37: 43 1-445.

48. Myatt L, Brockman DE, Eis AL, Pollock JS. (1993) Immunohistochemical localization of nitric oxide synthase in the human placenta. Placenta 14: 487-495.

49. Buttery LD, McCarthy A, Springal DR, et al. (1994) Endothelial nitric oxide synthase in the human placenta: regional distribution and proposed regulatory role at the feto-maternal interface. Placenta 15: 257-265.

50. Rutherford RA, McCarthy A, Sullivan MH, Elder MG, Polak J, Wharton MJ. (1995) Nitric oxide synthase in human placenta and umbilical cord from normal, intrauterine growth-retarded and pre-eclamptic pregnancies. Br. J. Pharmacol. 116: 3099-3109.

51. Odrcich MJ, Graham CH, Kimura KA, et al. (1998) Heme oxygenase and nitric oxide synthase in the placenta of the guinea-pig during gestation. Placenta 19: 509-516.

52. Yet S-F, Perrella MA, Layne MD, et al. (1999) Hypoxia induces severe right ventricular dilatation and infarction in heme oxygenase-1 null mice. J. Clin. Invest. 103: R23-R29.

53. Durante W, Kroll MH, Christodoulides N, Peyton KJ, Schafer AI. (1997) Nitric oxide induces heme oxygenase-1 gene expression and carbon monoxide production in vascular smooth muscle cells. Circ. Res. 80: 557-564.

54. Moncada S. (1997) Nitric oxide in the vasculature: physiology and pathophysiology. Ann. NY Acad. Sci. 811: 60-67.

55. Frusca T, Morassi L, Pecorelli S, Grigolato P, Gastaldi A. (1989) Histological features of uteroplacental vessels in normal and hypertensive pregnancies in relation to birthweight. $\mathrm{Br}$. J. Obstet. Gynaecol. 96: 835-839.

56. Brosens I, Dixon HG, Robertson WB. (1977) Fetal growth retardation and the arteries of the placental bed. Br. J. Obstet. Gyn. 84: 656664.

57. Nanaev A, Chwalisz K, Frank H, Kohnen G, 
Hegele-Hartung C, Kaufmann, P. (1995) Physiological dilation of uteroplacental arteries in the guinea pig depends on nitric oxide synthase activity of extra villous trophoblast. Cell Tissue Res. 282: 407-421.

58. Ahmed A, Dunk C, Kniss D, Wilkes M. (1997) Role of VEGF receptor-1 (Flt-1) in mediating calcium-dependent nitric oxide release and lim- iting DNA synthesis in human trophoblast cells. Lab. Invest. 76: 779-791.

59. Lyall F, Barber A, Bulmer JN, Myatt L, Robson SC. (1999) Hemoxygenase expression in human placenta and placental bed implies a role for carbon monoxide in regulation of implantation and placental function. J. Soc. Gynecol. Invest. 6: 54a (Abstr.). 